\title{
Pemilihan Susu Formula Menggunakan Metode Multi Attribute Utility Theory (MAUT)
}

\author{
Selection of Formula Milk Using the Method Multi Attribute Utility Theory (MAUT)
}

\author{
Ratna Sri Hayati ${ }^{1}$, Sri Lestari Rahayu ${ }^{2}$, Andi Sanjaya ${ }^{3}$ \\ Program Studi Informatika ${ }^{1}$ \\ Program Studi Rekayasa Perangkat Lunak ${ }^{2}$ \\ Program StudiInformatika ${ }^{3}$ \\ Fakultas Teknik dan Ilmu Komputer Universitas Potensi Utama ${ }^{1,2}$ \\ Universitas Nusa Mandiri ${ }^{3}$ \\ Email : $\underline{\text { ratnayach@gmail.com }}{ }^{1}$, aiyu.lestari13@gmail.com ${ }^{2}$, andi.sj7@gmail.com ${ }^{3}$
}

\begin{abstract}
Abstrak
Susu formula merupakan sumber nutrisi pada bayi yang tidak mendapatkan Air Susu Ibu (ASI). Susu formula juga memiliki kandungan gizi yang sangat tinggi. Kandungan gizi tersebut meliputi DHA, Karbohidrat, Protein, Lemak, Vitamin, Natrium dan lain sebagainya. Susu formula yang baik tidak menimbulkan gangguan saluran cerna seperti diare, muntah atau kesulitan buang air besar. batuk, sesak, dan gangguan kulit. Tujuan penelitian ini untuk mengetahui pemilihan susu formula oleh ibu balita. Dalam pemilihan susu formula yang ada dipasaran, diperlukan sebuah solusi dalam pengambilan keputusan. Dalam penelitian ini penulis menerapkan metode Multi Attribute Utility Theory(MAUT). Metode MAUT digunakan untuk menentukan sebuah alternatif pilihan berdasarkan bobot dan kriteria yang sudah ditentukan. Kemudian dilakukan proses perankingan yang akan menentukan alternatif yang terbaik. Alternatif pada penelitian ini ada 6 yaitu Susu S26, Susu Nutrilon Royal, Susu Bebelac, Susu Lagtogen, Susu Chilkid, dan Susu SGM. Sedangkan Kriteria yang digunakan ada 4 yaitu Harga Susu, Kandungan Gizi, Jenis Susu dan Ketersediaan Susu Dipasaran.
\end{abstract}

Kata kunci: Susu Formula, Sistem Pendukung Keputusan, Multi Attribute Utility Theory

\begin{abstract}
Formula milk is a source of nutrition for babies who do not get breast milk (ASI). Milk has very high calcium levels, the lactose content in milk helps absorption in the gastrointestinal tract, the substances contained in milk have a function to help growth and maintain health. Children who reach the age of toddlers must get adequate nutritional intake to support their growth. Good formula milk does not cause gastrointestinal disorders such as diarrhea, vomiting or difficulty defecating. cough, shortness of breath, and skin disorders. The purpose of this study was to determine the selection of formula milk by mothers of toddlers. In the selection of formula milk on the market, a solution is needed in decision making. In this study the authors apply the method of Multi Attribute Utility Theory (MAUT). The MAUT method is used to determine an alternative choice based on predetermined weights and criteria. Then a ranking process is carried out which will determine the best alternative. There are 6 alternatives in this study, namely S26 Milk, Nutrilon Royal Milk, Bebelac Milk, Lagtogen Milk, Chilkid Milk, and SGM Milk. While the criteria used are 4, namely Milk Price, Nutritional Content, Type of Milk and Availability of Milk in the Market.
\end{abstract}

Keywords: Formula Milk, Decision Support Systems, Multi Attribute Utility Theory

\section{PENDAHULUAN}

Pada umumnya, kebiasaan seorang ibu untuk memenuhi zat gizi pada Bayi, asupan gizi yang paling penting berasal dari Air Susu Ibu (ASI). Pemberian ASI eksklusif pertama kali diberikan pada bayi usia 0-6 bulan. Setelah usia bayi 6 bulan, dapat dilanjutkan sampai usia bayi mencapai 2 tahun. Namun demikian, ada juga ibu bayi yang memberikan Makanan Pendamping ASI (MPASI) setelah bayi berusia 6 bulan untuk menambah kebutuhan gizi. 
Meskipun ASI sudah banyak diberikan ke bayi, tetap saja bayi butuh gizi tambahan yang bisa didapat dari makanan pendamping selain ASI. MPASI dapat berupa makanan berbahan dasar nasi, atau bahan pokok yang mengandung karbohidrat ada juga yang hanya memberikan susu formula sebagai penambah ASI. Tidak menutup kemungkinan MPASI pilihan ibu balita diperoleh dari bubur instan yang dijual dipasaran. Kebanyakan ibu bayi tidak memahami kapan waktu yang tepat dalam memberikan MPASI kepada bayi mereka. Ada beberapa ibu bayi yang memberikan MPASI diatas 6 bulan bahkan ada yang memberikannya diawal kelahiran. Pemilihan MPASI juga menjadi polemic yang sudah banyak dialami ibu bayi. Susu formula merupakan pilihan kedua bagi ibu balita untuk menambah asupan gizi untuk balitanya. Selain ASI, susu formula juga memiliki kandungan gizi yang hampir sama dengan ASI. Bedanya, susu formula merupakan produk olahan susu yang berbahan dasar sapi, kedelai, asam amino maupun protein terhidrolisa parsial. Ibu bayi bisa memilih Susu Formula yang sesuai dengan kebutuhan anaknya. Karena susu formula memiliki berbagai jenis dan merek. Banyaknya merk produk susu formula juga menimbulkan dilemma para ibu balita, karena semakin banyak merk susu, semakin bervariasi harga dan kandungan gizinya, semakin sulit bagi ibu balita dalam memutuskan produk mana yang akan dipilih untuk memberikan asupan gizi bagi anaknya.

Ibu balita membutuhkan sistem pendukung keputusan dalam menentukan pilihannya. Dari banyaknya jenis dan merk susu formula, ibu balita yang disebut juga sebagai konsumen dikelompokkan menjadi 2 kategori. Kategori pertama disebut dengan kelas menengah keatas. Konsumen yang dikategorikan sebagai kelas menengah keatas lebih banyak memilih merk susu formula yang terkenal atau yang memiliki harga tinggi/mahal. Sedangkan konsuumen kategori kedua disebut sebagai kelas menengah kebawah yang lebih mengutamakan harga dibanding kualitas produk ataupun merk susu formula untuk balita mereka. Hal ini dikarenakan pada konsumen kelas menengah kebawah lebih menyesuaikan kemampuan mereka membeli susu formula berdasarkan perekonomian mereka. Apabila ibu balita memilih susu formula yang tidak sesuai dengan kebutuhan balitanya dapat mengakibatkan gangguan sistem pencernaan yang berdampak pada organ vital lainnya. Gangguan sistem pencernaan yang dialami balita secara terus menerus dapat membahayakan tumbuh kembangnya.

Dari latar belakang yang telah dijelaskan diatas, penulis mengamati permasalahan tersebut dan mengambil suatu langkah penelitian bahwa perlu dibuat sistem pendukung keputusan yang dapat digunakan oleh ibu balita/konsumen untuk membantu mereka dalam memilih susu formula balita yang terbaik. Dengan adanya sistem tersebut konsumen dapat dengan mudah memutuskan susu apa yang sesuai dengan kebutuhan anak dan sesuai dengan kesanggupan ibu balita tersebut dengan tetap mempertimbangkan prioritas kandungan gizi yang terdapat pada susu balita sesuai dengan kebutuhan. Pada penelitian ini, metode yang digunakan penulis dalam Sistem Pendukung Keputusan ini adalah Multi Attribute Utility Theory $(M A U T)$. Dengan adanya perhitungan bobot kriteria menggunakan metode MAUT, akan diperoleh hasil akhir dalam bentuk perangkingan dari nilai kriteria setiap alternative yang ada. Hasil penelitian ini dapat memberikan rekomendasi susu formula yang sesuai dengan kebutuhan oleh ibu balita berdasarkan kriteria yang telah ditetapkan.

Dalam melakukan penelitian ini, penulis telah beberapa kali mereview jurnal atau penelitian yang dilakukan oleh peneliti terdahulu. Salah satu diantaranya adalah penelitian yang dilakukan oleh Ristiani berjudul Model Sistem Pendukung Keputusan Pemilihan Susu Formula Terbaik Bagi Balita Menggunakan Fuzzy Multiple Attribute Decision Making (FMADM). Perhitungan dalam penelitian ini menggunakan metode Simple Additive Weighting (SAW). Peneliti menghitung nilai dari 3 alternatif yang telah ditentukan sehingga hasil yang diperoleh adalah V1 (SGM) memiliki nilai tertinggi yaitu 3,660 dan ditetapkan sebagai alternative terbaik[1].

Penelitian kedua yang penulis gunakan sebagai bahan referensi dalam penelitian ini adalah penelitian yang dilakukan oleh Husni'ah, U dengan judul Sistem Pendukung Keputusan Pemilihan Susu Formula Untuk Anak Usia 1-3 Tahun Dengan Menggunakan Metode AHP. Kriteria yang digunakan pada penelitian ini sesuai dengan peraturan menteri kesehatan Nomor 49 tahun 2014 yaitu karbohidrat, protein, energy total, dan lemak total. Hasil dari penelitian ini adalah sistem yang dirancang dapat mempermudah para ibu dalam pemilihan susu formula yang dapat memenuhi kebutuhan gizi pada anak, sehingga para ibu dapat dengan mudah untuk mengambil keputusan dalam menentukan rekomendasi susu 
formulayang terbaik [2].

Bobby R, dkk melakukan penelitian dengan mengkombinasi Metode AHP dan WP Dalam Sistem Pendukung Keputusan Pemilihan Susu Formula Balita. Analisa kebutuhan sistem pada penelitian ini menggunakan analisa PIECES. Dalam perancangannya, terdapat proses pengolahan nilai bobot, data susu, perbandingan berpasangan, dan proses Normalisasi. Kemudian user hanya input data susu, kriteria serta nilai bobotnya. Tujuan penelitian ini adalah mempermudah orang tua dalam pemilihan susu formula yang terbaik untuk anaknya[3].

Penelitian selanjutnya dilakukan oleh Fitriati, D dengan judul Perangkingan Jenis Susu menggunakan Metode Simple Additive Weighting (SAW). Metode ini digunakan peneliti untuk menentukan alternative, bobot nilai dan kriteria. Alternatif terbaik diperoleh dari hasil perangkingan. Kelebihan dari metode ini adalah terletak pada sistem analisisnya. Analisis metode SAW sangat tepat karena didasarkan pada nilai bobot preferensi dan nilai kriteria. Hasil penelitian ini adalah tinggat akurasi perhitungan dengan metode SAW bernilai 63,33\% dan menggunakan sampel sebanyak 30 data [4].

Penelitian berikutnya dilakukan oleh Imandasari dkk dengan judul Analisis Metode MAUT Pada Pemilihan Deodorant. Dari beberapa metode sistem pendukung keputusan yang ada, peneliti menggunakan metode MAUT dikarenakan metode ini dapat memberikan alternatif terbaik dan hasil akhir terbaik dalam waktu yang cepat, tepat dan akurat. Hasil penelitian ini adalah deodorant yang menjadi rekomendasi terbaik adalah deodorant Nature's Gate Organics Fruit Blend dengan nilai 0,73. Deodorant ini menjadi rekomendasi kepada konsumen karena aman untuk kulit dan terhindar dari iritasi pada kulit [5].

Penelitian yang dilakukan oleh Novita Sari, Rita dan Ratna Sri Hayati, (2019), Penerapan Metode Simple Additive Weighting Dalam Pemilihan Rumah Kos menjadi acuan penulis dalam memilih kriteria dalam penelitian ini. Hasil penelitian ini memberikan rekomendasi Rumah Kos bagi konsumen berdasarkan kebutuhan. Metode yang digunakan dalam perhitungan kriteria adalah SAW. Kriteria yang digunakan ada 8 yaitu harga kos, jarak, fasilitas, keamanan dan kebersihan, sedangkan alternatifnya ada 3 yaitu Rumah Kos A, Rumah Kos B, dan Rumah Kos C.

Berdasarkan latar belakang diatas, penelitian ini akan membahas tentang alternatif yang dipilih ibu balita berdasarkan kriteria yang telah ditetapkan sebelumnya. Adapun solusi yang ditawarkan penulis untuk ibu balita adalah dengan mengimplementasikan metode MAUT dalam Pemilihan Susu Formula dalam bentuk sistem pendukung keputusan. Hasil penelitian ini akan menunjukkan urutan alternatif dari peringkat pertama sampai dengan peringkat akhir.

\section{METODE PENELITIAN}

Penelitian ini menggunakan metode Multi Attribute Utility Theory (MAUT) untuk pemilihan susu formula. Dalam penelitian ini, peneliti menggunakan data kuantitatif yang diperoleh dari sampel produk dan hasil interview kepada ibu balita. Metode ini sering dikenal sebagai metode penjumlahan terbobot. Metode MAUT menerapkan perhitungan evaluasi total $V(x)$ dari alternatif yang dihitung sebagai bobot yang akan dijumlahkan dengan

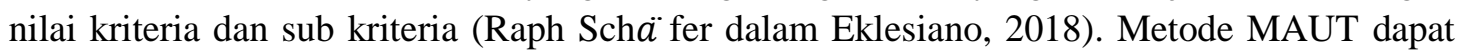
dikatakan sebagai teknik untuk mendukung pengambilan keputusan apabila si pengambil keputusan diwajibkan untuk memilih 1 dari banyak alternatif yang ada. Alternatif bisa berupa $r$ yang tersedia dimanapun sesuai kondisi tertentu (Sylvia, 2011). Langkah -langkah perhitungan dengan menggunakan metode MAUT adalah :

\section{Penentuan Alternatif dan Kriteria}

Alternatif pada penelitian ini ada 6 yaitu Susu S26, Susu Nutrilon Royal, Susu Bebelac, Susu Lagtogen, Susu Chilkid, dan Susu SGM. Sedangkan Kriteria yang digunakan ada 4 yaitu Harga Susu, Kandungan Gizi, Jenis Susu dan Ketersediaan Susu Dipasaran. 
2. Penentuan Bobot

Penentuan bobot kriteria diperoleh dari hasil interview ibu balita dengan total persentasi $100 \%$.

3. Pembuatan Matriks Ternormalisasi

Matriks ternormalisasi dibuat setelah penentuan bobot kriteria dihitung menggunakan persamaan (1). Bobot kriteria pada matrik ternormalisasi sesuai dengan nilai sub kriteria yang telah diperoleh dari hasil interview ibu balita.

4. Pembuatan Persamaan Normalisasi Matriks Keputusan

Matriks keputusan dibuat dengan menentukan nilai maksimum dan nilai minimum dari bobot nilai kriteria dan alternative.

5. Penjumlahan Hasil Perkalian (Hasil Normalisasi dengan Bobot Kriteria)

Hasil penjumlahan dibuat dalam bentuk perangkingan berdasarkan nilai akhir dari alternative yang telah ditetapkan.

Berikut ini tahapan - tahapan dimulainya penelitian sampai hasil rekomendasi ditemukan yang dapat dilihat pada gambar flowchart dibawah ini.

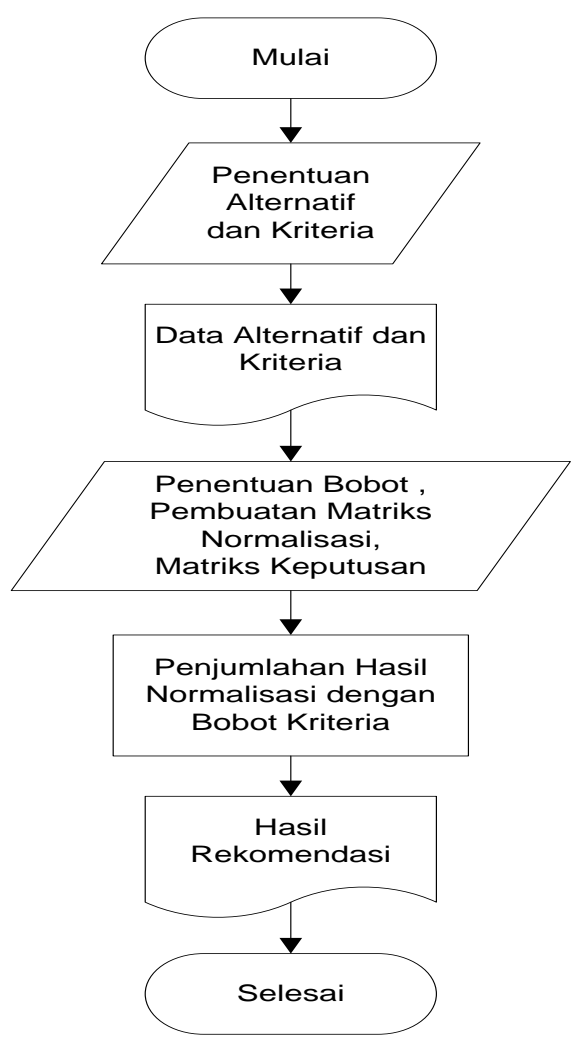

Gambar 1. Flowchart Proses Pemilihan Susu Formula

Data yang digunakan dalam penelitian ini terdiri dari 6 (enam) Alternatif, 4 (empat) Kriteria dan masing - masing kriteria memiliki 3 (tiga) sub kriteria. Kriteria ditentukan berdasarkan produk dan konsumen (ibu balita). Kriteria tersebut adalah harga susu, kandungan gizi, jenis susu, dan ketersediaan susu di pasaran. Perhitungan Metode MAUT dapat dirumuskan sebagai berikut:

$\mathrm{U}(x)=\frac{x-x_{1}^{-}}{x_{1}^{+}-x_{1}^{-}}$. 
keterangan:

$$
\begin{aligned}
\mathrm{x} & =\text { Bobot Kriteria } \\
x_{1}^{-} & =\text {Bobot Terburuk kriteria ke }-1 \text { di alternatif } \mathrm{x} \\
x_{1}^{+} & =\text {Bobot Terbaik kriteria ke }-1 \text { di alternatif } \mathrm{x}
\end{aligned}
$$

Dengan $\mathrm{U}(\mathrm{x})$ adalah rating nilai matriks dari alternatif Ai pada kriteria $\mathrm{Cj} ; \mathrm{i}=0, \ldots . . \mathrm{m}$ dan $\mathrm{j}=0, \ldots . . \mathrm{n}$

Nilai preferensi untuk setiap alternatif (Vi) diberikan berdasarkan persamaan berikut:

$\mathrm{V}(x)=\sum_{i=1}^{n} w_{i} . v_{i}(x)$

keterangan :

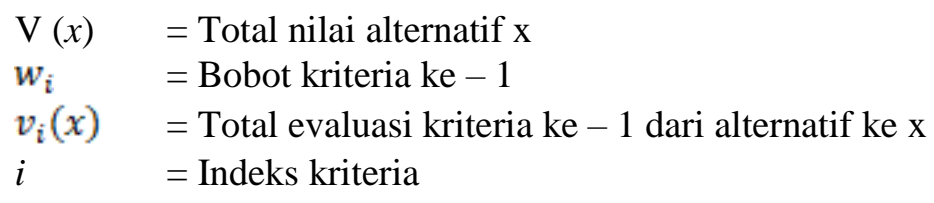

Utilitas untuk rating ternormalisasi dari setiap alternatif yang ditentukan dalam penelitian untuk menemukan hasil akhir dari nilai bobot alternatif $\mathrm{ke}-\mathrm{x}$, dalam skala $0-1$ disebut sebagai $\mathrm{U}(x)$ yang tertuang pada persamaan (3) dibawah ini:

Penelitian ini juga menggunakan aturan Schäfer dengan memberikan nilai dari tingkat kepentingan dari bobot yang diberikan adalah:

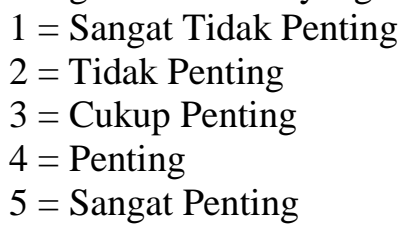

Untuk menghitung nilai bobot relatif pada setiap kriteria menggunakan persamaan (3) berikut ini:

$w_{i}=\frac{w_{i}^{g}}{\sum w_{i}^{l}}$

keterangan :

$$
\begin{array}{ll}
w_{i} & =\text { Bobot relatif kriteria ke }-1 \\
\sum w_{i}^{y} & =\text { Jumlah bobot dari setiap kriteria } \\
w_{i}^{y} & =\text { Jumlah tingkat kepentingan bobot dari setiap kriteria }
\end{array}
$$

\section{HASIL DAN PEMBAHASAN}

Penelitian ini menggunakan empat kriteria dan enam alternatif. Adapun kriteria yang digunakan adalah Harga Susu, Kandungan Gizi, Jenis Susu dan Ketersediaan Susu Dipasaran dan memiliki 3 sub kriteria pada masing-masing kriteria tersebut. Kriteria dan bobot dari setiap kriteria dapat dilihat pada tabel 1 berikut ini: 
Tabel 1. Kriteria dan Bobot

\begin{tabular}{|c|c|c|c|c|}
\hline No & Kriteria & Sub Kriteria & Nilai & Bobot \\
\hline \multirow[t]{3}{*}{1} & Harga Susu (C1) & Mahal & 10 & \multirow{3}{*}{$25 \%$} \\
\hline & & Sedang & 20 & \\
\hline & & Murah & 70 & \\
\hline \multirow[t]{3}{*}{2} & Kandungan Gizi (C2) & Tinggi & 80 & \multirow{3}{*}{$40 \%$} \\
\hline & & Cukup & 20 & \\
\hline & & Rendah & 0 & \\
\hline \multirow[t]{3}{*}{3} & Jenis Susu (C3) & Sapi & 80 & \multirow{3}{*}{$20 \%$} \\
\hline & & Soya & 15 & \\
\hline & & Asam Amino & 5 & \\
\hline \multirow[t]{3}{*}{4} & Ketersediaan Di Pasaran (C4) & Banyak & 100 & \multirow{3}{*}{$15 \%$} \\
\hline & & Cukup Banyak & 0 & \\
\hline & & Langka & 0 & \\
\hline
\end{tabular}

1. Harga Susu

Pada kriteria harga susu terdapat 3 sub kriteria yang ditentukan peneliti berdasarkan pilihan ibu bayi. Harga Susu yang Mahal memiliki nilai lebih rendah yaitu 10, harga susu yang Sedang memiliki nilai 20 dan harga susu yang Murah memiliki nilai tertinggi yaitu 70 . Harga Susu menjadi kriteri pertama karena dari hasil pengamatan peneliti, Konsumen kelas menengah keatas lebih banyak memilih merk susu formula yang terkenal atau yang memiliki harga tinggi/mahal karena mereka meyakini bahwa produk apapun yang memiliki kualitas bagus pastinya memiliki harga yang mahal. Sedangkan konsumen kelas menengah kebawah lebih mengutamakan nilai harga dibanding kualitas dan nilai gizi susu formula untuk balita mereka. Hal itu dilatarbelakangi oleh kemampuan ibu balita membeli susu balita dengan harga yang rendah sesuai dengan tingkat ekonominya.

2. Kandungan Gizi

Pada kriteria kandungan gizi terdapat 3 sub kriteria yaitu tinggi, cukup dan rendah. Kriteria kandungan gizi memberikan informasi mengenai kandungan DHA, protein, karbohidrat, lemak, natrium dan sebagainya yang terdapat pada susu formula. Jika kandungan gizi yang ada pada susu formula tinggi maka nilainya tinggi, dan jika kandungan gizi yang terdapat pada susu rendah maka nilai yang diberikan yaitu 0 . Kandungan gizi berada pada kriteria kedua karena dari hasil penelitian dengan ibu balita, selain melihat harga ibu balita juga memprioritaskan kandungan gizi yang dapat mendukung perkembangan pertumbuhan balita secara maksimal. Hal ini juga erat kaitannya dengan harga susu yang dikenal masyarakat ada harga ada kualitas.

3. Jenis Susu

Kriteria jenis susu memiliki 3 sub kriteria yang banyak dikonsumsu oleh bayi berdasarkan hasil interview oleh ibu bayi. Jenis susu yang paling bagus dan banyak dikonsumsi bayi pada umumnya adalah jenis susu sapi dengan diberikan nilai tertinggi yaitu 80. Jenis susu soya biasa dikonsumsi oleh bayi yang alergi susu sapi dan jenis susu asam amino memiliki nilai terendah karena jenis ini hanya dikonsumsi oleh bayi yang mengalami gangguan pencernaan.

4. Ketersediaan di Pasaran

Kriteria ini ditetapkan untuk memberikan informasi tentang mudah atau tidaknya susu formula yang dijadikan alternative pada penelitian ini diperoleh dipasaran. Karena tidak semua daerah menyediakan segala macam merek susu formula secara lengkap untuk dijual. Hal itu dilatarbelakangi dengan harga susu dan juga kandungan gizi yang bervariasi dan disesuaikan dengan minat pembeli (ibu bayi). Sub kriteria pada kriteria ini ada 3 yaitu Banyak, Cukup Bayak, dan Sedang. Pada umumnya, susu dengan kualitas terbaik memiliki 
harga yang mahal dan kandungan gizi yang tinggi. Susu balita ini akan mudah ditemukan didaerah Kota. Karena hanya konsumen kelas menengah keatas yang biasanya memilih susu tersebut. Sedangkan yang banyak dipasaran adalah susu dengan harga murah dan kandungan gizi sedang. Hal tersebut dikarenakan peminat susu tersebut kebanyakan dari konsumen kalangan menengah kebawah yang tinggalnya dipinggiran kota bahkan di pedesaan. Dapat disimpulkan bahwa ketersediaan susu disesuaikan dengan pangsa pasar.

Data penelitian yang diperoleh dari angket yang diberikan kepada ibu balita saat interview berisi tentang alternative dan sub kriteria, dimana ibu balita yang memberikan susu formula pada anaknya memiliki beberapa penilaian yang dapat dilihat pada tabel 2 dibawah ini:

Tabel 2. Data Penelitian

\begin{tabular}{|l|c|c|c|c|}
\hline \multicolumn{1}{|c|}{ ALTERNATIF } & HARGA & KANDUNGAN & JENIS & KETERSEDIAAN \\
\hline Susu S26 & Mahal & Tinggi & Sapi & Cukup Banyak \\
\hline Susu Nutrilon Royal & Mahal & Tinggi & Soya & Cukup Banyak \\
\hline Susu Bebelac & Sedang & Cukup & Sapi & Banyak \\
\hline Susu Lactogen & Sedang & Cukup & Sapi & Banyak \\
\hline Susu Chilkid & Sedang & Cukup & Soya & Banyak \\
\hline Susu SGM & Murah & Cukup & Sapi & Banyak \\
\hline
\end{tabular}

Dari data penelitian yang diperoleh, informasi tersebut ditampilkan dalam bentuk matriks keputusan. Matriks keputusan memberikan informasi tentang nilai bobot dari masing - masing alternative berdasarkan kriteria- kriteria yang telah ditetapkan. Matriks Keputusan tersebut dapat dilihat pada tabel 3 berikut ini:

Tabel 3 Matriks Keputusan

\begin{tabular}{|l|l|c|c|c|c|}
\hline NO & \multicolumn{1}{|c|}{ ALTERNATIF } & C1 & C2 & C3 & C4 \\
\hline 1 & Susu S26 & 50 & 80 & 70 & 30 \\
\hline 2 & Susu Nutrilon & 45 & 70 & 80 & 35 \\
\hline 3 & Susu Bebelac & 60 & 50 & 80 & 40 \\
\hline 4 & Susu Lactogen & 60 & 50 & 80 & 40 \\
\hline 5 & Susu Chilkid & 55 & 50 & 80 & 80 \\
\hline 6 & Susu SGM & 70 & 50 & 80 & 80 \\
\hline & MAX & 70 & 80 & 80 & 80 \\
\hline & MIN & 45 & 50 & 70 & 30 \\
\hline
\end{tabular}

Setelah melakukan data konversi dari matriks keputusan, selanjutnya masuk kedalam tahap penyelesaian menggunakan metode MAUT. Langkah pertama yang dilakukan dalam penyelesaian metode MAUT adalah melakukan normalisasi matriks menggunakan persamaan (1). Berikut ini merupakan tabel normalisasi matriks menggunakan persamaan (1) yang tertuang pada tabel 4.

Tabel 4 Normalisasi Matriks

\begin{tabular}{|l|l|c|c|c|c|}
\hline NO & ALTERNATIF & C1 & C2 & C3 & C4 \\
\hline 1 & Susu S26 & 1 & 1 & 0 & 1 \\
\hline 2 & Susu Nutrilon Royal & 0 & 1 & 0 & 1 \\
\hline 3 & Susu Bebelac & 0 & 0 & 0.4 & 0 \\
\hline 4 & Susu Lactogen & 1 & 1 & 1 & 0 \\
\hline 5 & Susu Chilkid & 0.4 & 1 & 0 & 1 \\
\hline 6 & Susu SGM & 1 & 1 & 0 & 1 \\
\hline
\end{tabular}

Nilai preferensi dari 4 kriteria yang terdapat pada masing - masing alternatif dapat dilihat 
pada hasil berikut ini:
1. Harga Susu
$: 0.6$
2. Kandungan Gizi
$: 0.8$
3. Jenis Susu
$: 0.2$
4. Ketersediaan Dipasaran
$: 0.7$

Setelah bobot preferensi ditentukan, langkah selanjutnya adalah melakukan perhitungan hasil normalisasi dikalikan bobot prefernsi yang sudah ditentukan diatas menggunakan persamaan (1):

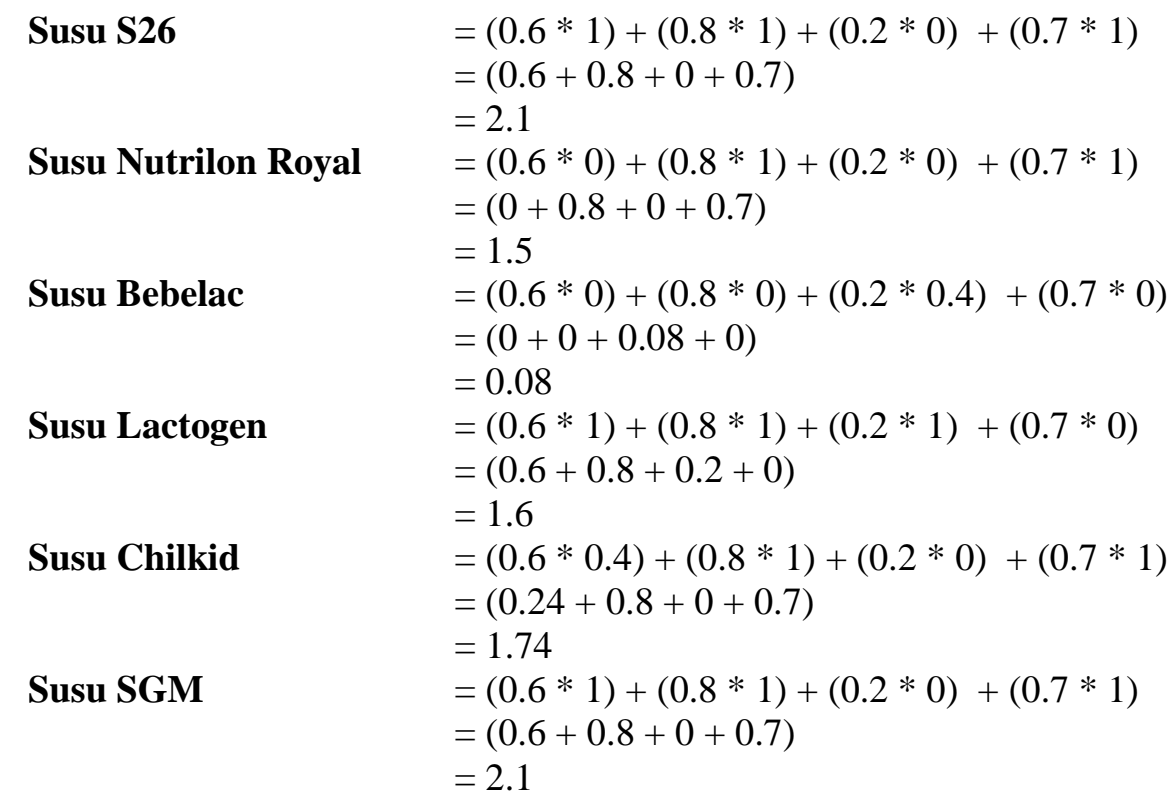

Selanjutnya dilakukan penjumlahan hasil perkalian dari hasil normalisasi dengan bobot kriteria menggunakan persamaan (2). Setelah hasil perkalian normalisasi dengan bobot diperoleh selanjutnya masuk dalam tahap perangkingan untuk seluruh alternatif. Hasil perkalian normalisasi dengan bobot dan perangkingan keenam alternatif, dapat dilihat pada tabel 5 .

Tabel 5 Nilai Akhir dan Perangkingan

\begin{tabular}{|l|l|c|c|}
\hline NO & ALTERNATIF & JUMLAH & RANGKING \\
\hline 1 & Susu S26 & 2.1 & 1 \\
\hline 2 & Susu Nutrilon Royal & 1.5 & 4 \\
\hline 3 & Susu Bebelac & 0.08 & 5 \\
\hline 4 & Susu Lactogen & 1.6 & 3 \\
\hline 5 & Susu Chilkid & 1.74 & 2 \\
\hline 6 & Susu SGM & 2.1 & 1 \\
\hline
\end{tabular}

Dari hasil perhitungan menggunakan metode MAUT, susu yang menjadi rekomendasi adalah Susu S26 dan Susu SGM dengan nilai 2.1 menduduki peringkat 1. Sedangkan Susu Chilkid berada pada peringkat 2 dengan nilai 1.74, Susu Lactogen berada pada peringkat 3 dengan nilai 1.6, untuk peringkat 4 ada Susu Nutrilon Royal dengan nilai 1.5, ditutup dengan peringkat 5 yaitu Susu Bebelac dengan nilai 0.08 . 


\section{KESIMPULAN}

Kesimpulan yang dapat diambil berdasarkan hasil penelitian yang telah dilakukan adalah:

1. Perancangan Sistem Pendukung Keputusan dengan menerapkan metode MAUT berhasil memberikan rekomendasi kepada ibu balita/konsumen untuk mengambil keputusan dalam pemilihan susu formula.

2. Sistem yang dirancang membahas implementasi metode MAUT dalam pemilihan susu formula untuk balita.

3. Dengan menerapkan metode MAUT, hasil rekomendasi yang diperoleh memudahkan ibu balita untuk memutuskan susu formula yang cocok dikonsumsi balitanya.

4. Dari hasil perhitungan 6 alternatif menggunakan metode MAUT, Susu S26 dan Susu SGM memiliki nilai tertinggi yaitu sebesar 2.1, Susu Chilkid memiliki nilai sebesar 1.74, Susu Lactogen memiliki nilai sebesar 1.6, Susu Nutrilon Royal memiliki nilai sebesar 1.5, dan Susu Bebelac memiliki nilai sebesar 0.08. Maka dapat disimpulkan bahwa Susu S26 dan Susu SGM memiliki nilai tertinggi yang menjadi peringkat 1 pilihan ibu balita.

\section{SARAN}

Untuk penelitian selanjutnya dapat mengembangkan penelitian ini dengan melakukan penelitian yang berfokus pada:

1. Implementasi Metode MAUT akan lebih akurat hasilnya apabila dalam perancangan Sistem Pendukung Keputusan menambahkan jumlah variabel subkriteria, dan penambahan jumlah alternatif.

2. Penelitian selanjutnya dapat mengkombinasi beberapa metode sebagai penunjang perhitungan nilai bobot agar hasil perangkingan lebih akurat.

3. Selain kombinasi metode, dapat juga dilakukan penelitian dengan fokus pada perbandingan metode dalam penentuan hasil akhir.

\section{UCAPAN TERIMA KASIH}

Peneliti mengucapkan terima kasih kepada pihak Universitas Potensi Utama yang telah memberikan dukungan financial dalam penelitian ini.

\section{DAFTAR PUSTAKA}

[1]. Ristiani, Model Sistem Pendukung Keputusan Pemilihan Susu Formula Terbaik Bagi Balita Menggunakan Fuzzy Multiple Attribute Decision Making (FMADM). Lampung, STMIK Pringsewu Lampung

[2]. Husniah, U, 2016, Sistem Pendukung Keputusan Pemilihan Susu Formula Untuk Anak Usia 1-3 Tahun Dengan Menggunakan Metode AHP,. Kediri, UNP Kediri.

[3]. Rachmatullah, R., \& Dewi, S. N. (2016). "Implementasi Metode AHP Dan WP Dalam Sistem Pendukung Keputusan Pemilihan Susu Formula Balita".jurnal ilmiah.

[4]. Fitriati, D, Perangkingan Jenis Susu Untuk Balita Non-ASI Dengan Metode Simple Additive Weighting (SAW), Jurnal Teknologi Terpadu Vol. 5, No. 1, Juli 2019.

[5]. Imandasari, T, Analisis Metode MAUT Pada Pemilihan Deodorant, SAINTEKS,Januari 2019, Hal 736-739.

[6]. Ningsih, Iriyanti, 2012, Pemilihan Susu Formula Bayi 0 - 6 Bulan Berdasarkan Komposisi Zat Gizi Atau Harga Jual (Studi Kasus Di Rumah Sakit Dr.Moewardi Surakarta), Surakarta, Universitas Sebelas Maret

[7]. Hidayatullah, Arif, Sistem Pemilihan Rumah Kos Terbaik Di Sekitar Unhasy Dengan Metode Multi Attribute Utility Theory (Maut) Berbasis WEB, INOVATE. Volume 03 Nomor 02 Tahun 2019

[8]. E. Satria, N. Atina, M. E. Simbolon, and A. P. Windarto, "SPK : ALGORITMA MULTI-ATTRIBUTE UTILITY THEORY ( MAUT ) PADADESTINASI 
TUJUAN WISATA LOKAL DI KOTA SIDAMANIK," CESS (Journal Comput. Eng. Syst. Sci., vol. 3, no. 2, pp. 75-79, 2018.

[9]. N. Hadinata, "Implementasi Metode Multi Attribute Utility Theory ( MAUT ) Pada Pendukung Keputusan dalam Menentukan Penerima Kredit," J. SISFOKOM, vol. 7, no. September, pp. 87-92, 2018.

[10]. T. Imandasari and A. P. Windarto, "Penerapan Metode VIKOR Pada Pemilihan Popok Bayi Berdasarkan Jenis Kulit,” Semin. Nas. Sains Teknol. Inf., pp. 215-220, 2018.

[11]. D. R. Sari, A. P. Windarto, D. Hartama, and S. Solikhun, "Sistem Pendukung Keputusan untuk Rekomendasi Kelulusan Sidang Skripsi Menggunakan Metode AHP-TOPSIS," J. Teknol. dan Sist. Komput., vol. 6, no. 1, p. 1, 2018.

[12]. Jannah, Riadhil. 2015. Aplikasi Penerimaan Karyawan dengan Metode Multi Attribute Utility Theory. SATIN - Sains dan Teknologi Informasi, Vol. 1, No. 2, Desember 2015.

[13]. Hardinata, Novri. 2018. Implementasi Metode Multi Attribute Utility Theory (MAUT) Pada Sistem Pendukung Keputusan dalam Menentukan Penerima Kredit. Jurnal SISFOKOM, Volume 07, Nomor 02, September 2018.

[14]. Ramadiani. 2018. Sistem Pendukung keputusan pemilihan tenaga kesehatan teladan menggunakan metode Multi-Attribute Utility Theory. Jurnal Ilmiah Teknologi Sistem Informasi 5 (1) 2019 1-12 ISSN 2503-0477.

[15]. Novita Sari, Rita dan Ratna Sri Hayati, (2019), Penerapan Metode Simple Additive Weighting Dalam Pemilihan Rumah Kos, Cogito Smart Journal, Vol 5, No. 2, Desember 2019. 